\title{
Influencia del volumen de fibras y curado posterior sobre el comportamiento post - fisura de un concreto de ultra alto desempeño
} Influence of fiber volume and subsequent curing on post - crack
behavior of an ulltra high performance concrete (UHPC)

\author{
Nicolás González*, Jesús Castaño*, Yezid Alvarado ${ }^{1}$, Isabel Gasch** \\ * Pontificia Universidad Javeriana, Bogotá. COLOMBIA \\ ** Universitat Politècnica de València, Valencia. ESPAÑA
}

Fecha de Recepción: 28/07/2014

Fecha de Aceptación: 25/11/2014

PAG 220-233

\begin{abstract}
Resumen
En el presente artículo se evalúa el desempeño de un concreto de ultra alto desempeño reforzado con diferentes contenidos de fibras metálicas, el cual fue elaborado utilizando materiales accesibles en Colombia y con técnicas de fabricación convencional, es decir no se utilizaron presiones o temperaturas elevadas en la fabricación de los diferentes especímenes. A este concreto de ultra alto desempeño se le realizaron pruebas de resistencia a la compresión uniaxial, resistencia a la flexión y de igual forma se evaluó el comportamiento de viguetas fisuradas a diferentes edades, las cuales fueron sometidas a diferentes tiempos de curado, con el fin de determinar la resistencia residual a flexión de las mismas. Se ha observado que el contenido en fibras y la adherencia que se genere entre las mismas y la matriz de concreto son aspectos de gran importancia, con el fin de garantizar que no haya pérdida de la resistencia a la flexión, independientemente de la edad de fisuración.
\end{abstract}

Palabras claves: Concreto de ultra alto desempeño, resistencia a la compresión, post-fisura, concreto reforzado con fibras, resistencia a la flexión

\begin{abstract}
In this paper the performance of an Ultra-High Performance Concrete (UHPC) reinforced with different contents of metal fibers is evaluated. This concrete was produced using materials available in Colombia and conventional manufacturing techniques; ie no high temperatures or pressures in the manufacturing of different specimens were used. This UHPC was tested for uniaxial compressive strength and flexural strength. Furthermore, we evaluated the behavior of different ages cracked joists of different ages, which were subjected to different curing times in order to determine the residual bending strength., was evaluated. It has been observed We observed that the fiber content and adhesion to be generated between them the fibers and the concrete matrix are matters of great importance, in order to ensure no loss of flexural strength, regardless of the age of the cracking.
\end{abstract}

Keywords: Ultra high performance concrete (UHPC), compressive strength, postcracking, fiber reinforced concrete, flexural strength

\section{Introduction}

In the 90's, authors such as Bouygues (Resplendido, 2004) or Reda et al. (1999) took the first steps in research of Ultra High Performance Concrete (UHPC). The first application of UHPC in civil engineering was in 1997 for a pedestrian bridge in Sherbrooke, Canada (Resplendido, 2004; Acker et al., 2004). Later, it was used in other areas such as in the construction of the Cattenom and Civaux power plants (Resplendido, 2004) or research about the performance of steel tubes filled with UHPC (Tue et al., 2004).

While improvements have been made in concrete's ability to withstand compression, the definition of highstrength concrete has been changing over time. This is why the American Concrete Institute's Committee 363 recognizes that the definition of high-strength concrete is based on the specific geographical area, since it depends on the compression strengths that are produced in each region $(\mathrm{ACI}$ Committee 363, 2010).

\footnotetext{
${ }^{1}$ Autor de correspondencia / Corresponding author:

Pontificia Universidad Javeriana. Calle 40 No. 5-50 Ed. José Gabriel Maldonado, S.J., Bogotá, Colombia. Tel.: +57 13208320 (ext. 2718); fax: +57 13208320 (ext. 5398)

E-mail: alvarado.y@javeriana.edu.co
} 
Today, there are only a few methodologies for the design of concrete mixtures with compression strength levels above $83 \mathrm{MPa}$, with the exception of the model developed by De Larrard (1999), to measure various types of concrete, both conventional and high performance concrete. Given that there are no simplified methodologies for high-strength concrete mixtures, research in this area is very attractive, so as to find relationships that can be used to support the implementation of these materials in the industry.

One of the main characteristics of these mixtures is the high concentration of cement material. Some authors recommend that the content of cement material be above $900 \mathrm{~kg}$., which is composed of between 20\% to 25\% of silica fume and cement (Wang et al., 2012). Likewise, it is important to use high doses of super-plasticizers so as to proportionately reduce the ratio of water/cement. (Yang et al., 2010).

If metallic fibers are added into the process of the concrete mixture, they considerably improve the impact, fatigue and bending strengths, offering a large variety of applications, as well as technical and economic advantages. The ultra-high performance concrete, reinforced with metallic fibers, is a viable candidate to overcome low tensile strength and a lack of ductility of the concrete which are inherent characteristics of conventional concrete.

Adding metallic fibers to the concrete mixture increases ductility (Oh, 1992; Oh, 1994), weight-bearing capacity (Ashour et al., 1993), and shear stress strength (Campione et al., 2008). On the other hand, multiple authors (Ashour et al., 2000; Chunxiang et al., 1999) researched the flexural performance of beams made of concrete that was reinforced with high strength fibers.

To determine the optimal combination of materials for the concrete reinforced with metallic fibers, experimental compression strength tests were required, in addition to fluidity trials of the mixture, while considering that the maximum volume of fibers that can be used without an impact to handling is 2\%. (Markovic, 2006).

Many authors have researched multiple self-healing methods (Jonkers et al., 2010; Van Tittleboom et al., 2010). It is believed that the self-healing properties of cement materials are a combination of physical and chemical processes, including (a) the formation of calcium carbonate or calcium hydroxide, (b) the loss of concrete particles in the cracking of the concrete, (c) an additional hydration process of the cement that was not hydrated, and (d) the expansion of the concrete matrix in the cracked area given the high cement content and the low ratio of water and cement ( $W u$ et al., 2012). The self-healing benefits include not only the reduction of maintenance and repair costs, but also the reduction of $\mathrm{CO}_{2}$ emissions, since concrete production is very harmful to the environment. 
The objective of this research is to develop a UHPC with compression strength above $150 \mathrm{MPa}$, using materials that are easy to obtain in Colombia and preparation methods that do not require high pressure nor do they create additional heat which generating hydration. The implementation of these techniques is difficult to control and to provide to structures once the different structural and nonstructural elements in a conventional engineering project have been poured.

The goal was also to evaluate the mechanical behavior in response to the flexing of cracked UHPC, after submitting it to different curing periods, so as to evaluate if there is selfhealing of the concrete.

\section{Methodology}

\subsection{Description of the Materials}

So as to characterize the components of the mixture, we conducted physical-chemical tests that are described below:

- Morphological characterization of the granular materials used in the mixture's design with granulometry using the sieve technique (ASTM C117).

- Implementation of the granulometry of the finegrained inputs (cement, silica fume, and quartz dust) of the mixture, by using the laser technique for dust.

- Physical-mechanical characterization of the cementing materials, using compression cube tests (ASTM C109) and strength activity index (ASTM C311).

- Chemical and mineral characterization of the cement, using x-ray diffraction (DRX).

\subsection{Analysis of the material's mechanical performance}

To study the mechanical performance of the UHPCs, we conducted compression strength tests in accordance with standard ASTM C39. Then a modulus of rupture test was implemented, in line with standard ASTM C580; finally, a test of sudden residual flexural strength in accordance with standard ASTM C1399.

\subsection{Post-cracking performance of the UHPC}

We evaluated the flexural mechanical performance of the cracked UHPC, after subjecting them to different periods of humid curing. To achieve that, prismatic samples were taken to a controlled crack in a universal machine until a deflection of $0.2 \mathrm{~mm}$. (ASTM C1399). Those samples were stored for periods of 7 to 28 days, and then the responses of the samples were determined with a post-curing flexural strength test (ASTM C1399). 


\section{Anallysis of resullts}

The high performance concrete (UHPC) created in this research is a type of reactive powder (Aïtcin, 2000; Richard et al., 1995). The Fuller distribution method was used to determine the dosages of materials composing the concrete. The concrete mixtures produced were made with high levels of cement material (cement and silica fume) and a low water/cement ratio. Fine- grain sand, with a maximum diameter of $500 \mu \mathrm{m}$, and quartz powder, with an average diameter of $18 \mu \mathrm{m}$, were used as dry ingredients.

\subsection{Characterization of the Materials}

The properties of the individual materials, such as the granulometric distribution, specific mass and experimental compactness, weredetermined using an experimental method.

The materials used to manufacture the ultra-high resistant concrete were: Portland cement; silica fume; a super-plasticizer additive based on modified polycarboxylics, and two types of sand: the first(quartz powder) has granular dimensions between 2.4 to $85 \mu \mathrm{m}$ and the second type (sand60) between 140 to $500 \mu \mathrm{m}$; steel fibers (diameter of $18 \mu \mathrm{m}$, length of $13 \mathrm{~mm}$ and density of $7.90 \mathrm{~g} / \mathrm{cm}^{3}$ ).

The density values of the cement and silica fume, presented in Table 1, were determined with the Le Chatelier Flask, in line with standard ASTM C188. The specific gravity and absorption values for sand-60 and quartz powder were determined in line with the procedures established in standard ASTM C128.

Tabla 1. Densidad de los materiales

Table 1. Density of the materials

\begin{tabular}{|c|c|}
\hline Material & Densidad/Density $\left(\mathrm{g} / \mathrm{cm}^{3}\right)$ \\
\hline Cemento/Cement & 3.17 \\
\hline Humo de Sílice/Silica Fume & 2.65 \\
\hline Arena/Sand - 60 & 2.59 \\
\hline Polvo de Cuarzo (Arena - 100)/Quartz Powder (Sand - 100) & 2.51 \\
\hline
\end{tabular}

The fineness of the Portland cement was determined using the Blaine Fineness Apparatus, in line with the procedure described in standard ASTM C204. Its specific surface area was $3796.41 \mathrm{~cm}^{2} / \mathrm{g}$. It is important to note that this value is not specified in standard ASTM C1157 for Portland Cement. The amount of water required to prepare hydraulic cement paste, of normal consistency for later tests, was $26.1 \%$. 
This value was determined by following the procedure described in ASTM C187. Once the water/cement ratio was established, the setting time of this paste was measured, following the parameters outlined in ASTM C191. Given the results obtained from the tests of set times, initial and final set times of $170 \mathrm{~min}$. and $210 \mathrm{~min}$. respectively were measured. Table 2 presents a summary of the physical parameters of the Portland cement.

Tabla 2. Parámetros físicos del Cemento Portland

Table 2. Physical Parameters of Portland Cement

\begin{tabular}{cccc}
\hline Parámetros Físicos/ Physical Parameters & $\begin{array}{c}\text { Resultados Proyecto/ } \\
\text { Project Results }\end{array}$ & NTC - 121 & ASTM C1157 \\
\hline $\begin{array}{c}\text { Tiempo de fraguado inicial, mínimo } \\
\text { (min)/ Initial set time, minimum (min) }\end{array}$ & 60 & 60 & 45 \\
\hline $\begin{array}{c}\text { Tiempo de fraguado final, máximo (min)/ } \\
\text { Final set time, maximum (min) }\end{array}$ & 150 & 600 & 420 \\
\hline $\begin{array}{c}\text { Blaine, mínimo }\left(\mathrm{cm}^{2} / \mathrm{g}\right) / \text { Blaine, minimum } \\
\left(\mathrm{cm}^{2} / \mathrm{g}\right)\end{array}$ & 3796.41 & 2800 & 2800 \\
\hline
\end{tabular}

The method used to evaluate compatibility, as well as the saturation point of the plasticizer on the cement particles and silica fume, was the fluidity test of the pastes with a slump test ; for this type of concrete, we must verify that the diameter of the mixture is over $60 \mathrm{~cm}$.

The percentage of voids in the sand was determined by the test of compactness and vibration, in line with the procedures described in standard ASTM C29. The procedure was done with Sand-60 and Quartz Powder (Sand-100), with the results shown in Table 3.

Tabla 3. Porcentaje de vacíos de las Arenas

Table 3. Percentage of voids in the Sand

\begin{tabular}{|c|c|c|c|}
\hline \multicolumn{2}{|c|}{ Material } & $\begin{array}{c}\text { Polvo de Cuarzo/ } \\
\text { Quartz Dust }\end{array}$ & Arena/Sand - 60 \\
\hline \multirow{2}{*}{$\begin{array}{l}\text { Porcentaje de Vacíos/ } \\
\text { Percentage de Spaces }\end{array}$} & $\begin{array}{c}\text { Varillado/ } \\
\text { Measurement }\end{array}$ & $46.08 \%$ & $41.06 \%$ \\
\hline & $\begin{array}{l}\text { Vibrado/ } \\
\text { Vibration }\end{array}$ & $39.20 \%$ & $36.53 \%$ \\
\hline
\end{tabular}

The granulometric distribution of the cement, silica fume, quartz powder (sand-100) and sand-60 that make up the concrete mixture was determined with laser granulometry. Figure 1 shows the results of these particle size measurements, together with the mixtures that were made as part of the experimental design, so as to evaluate different properties, such as handling and compression strength. 


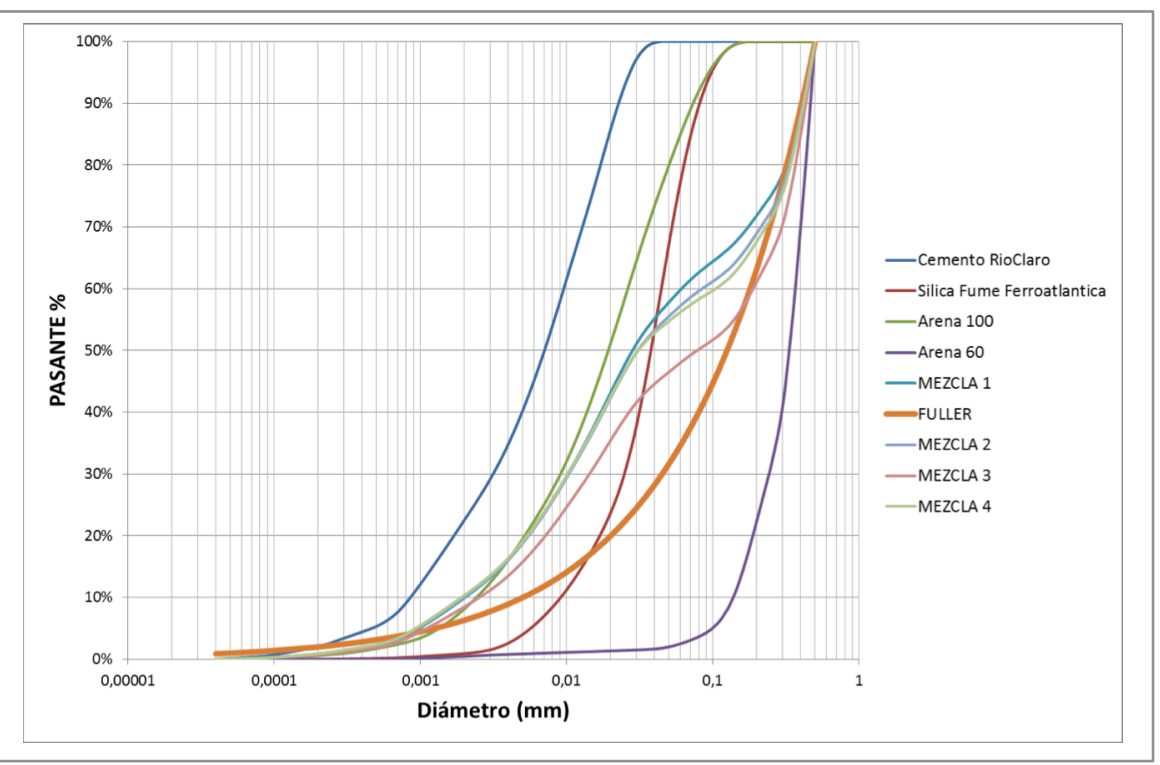

Figura 1. Granulometría láser de los materiales y mezclas propuestas Figure 1. Laser granulometry of the proposed materials and mixtures

The silica fume available in Colombia is not as finely grained; therefore, differing from the literature, the most finely grained input in our mixtures was quartz sandThis material is a component with a small enough diameter to fill the spaces between the cement and the silica fume. Also, when designing the mixture it was important to keep in mind the gradation of Sand- 60 .

Using a Scanning Electron Microscope (SEM), we observed the detail of the characteristics of each of the materials in the concrete mixture.

As shown in Figures 2 and 3, the particles of the inputs in the mixture are very angular and their surfaces are not well defined. Therefore, the water/cement ratio used in the mixture cannot be further reduced.

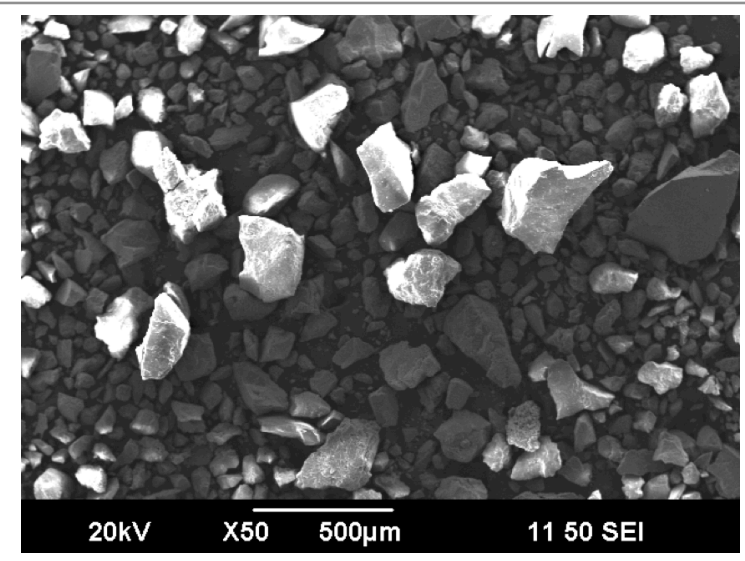

(a)

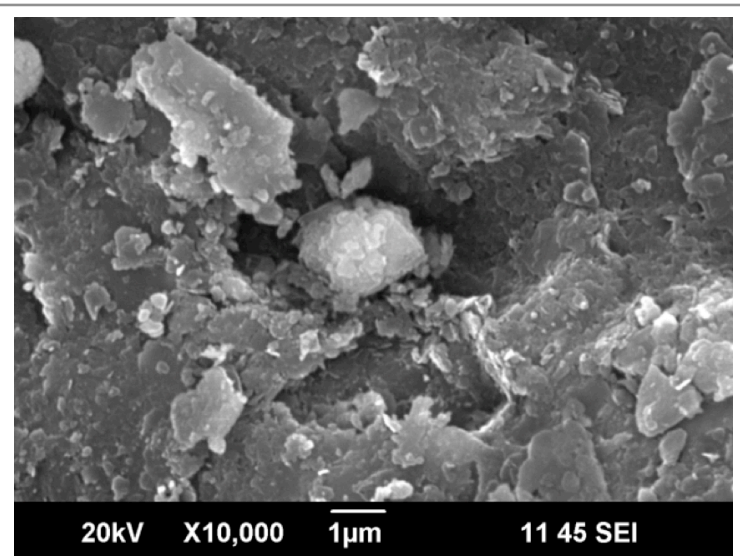

(b)

Figura 2. MEB, Arena - 60. (a) 50x, (b) 10000x

Figure 2. MEB, Sand -60. (a) 50x, (b) 1000x 


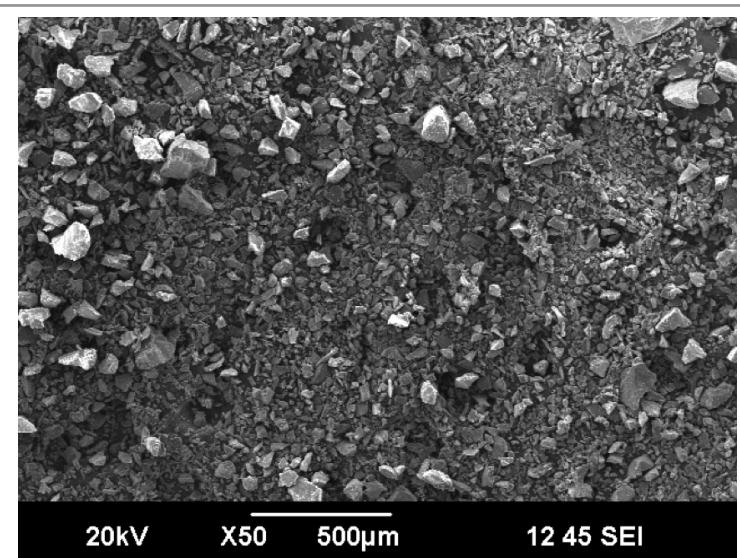

(a)

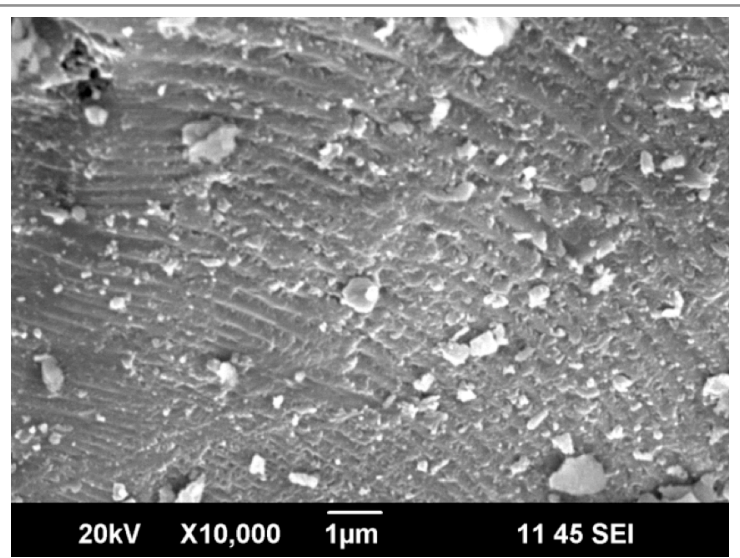

(b)

Figura 3. MEB, Polvo de cuarzo (Arena - 100). (a) 50x, (b) 10000x

Figure 3. MEB, Quartz powder (Sand-100). (a) 50x, (b) 1000x

In contrast with stone inputs, silica fume has the desired spherical form (Figure 4), allowing us to work with lower water/cement ratios. This material, due to its high silica content, plays an important role in the structure of the cement paste. It acts like a physical filler, increasing the compactness of the mixture. It considerably reduces the oozing of the fresh cement due to its large surface area and its ability to hold water, and it favors the Pozzolanic activity that is generated (Espinoza Montenegro, 2010).

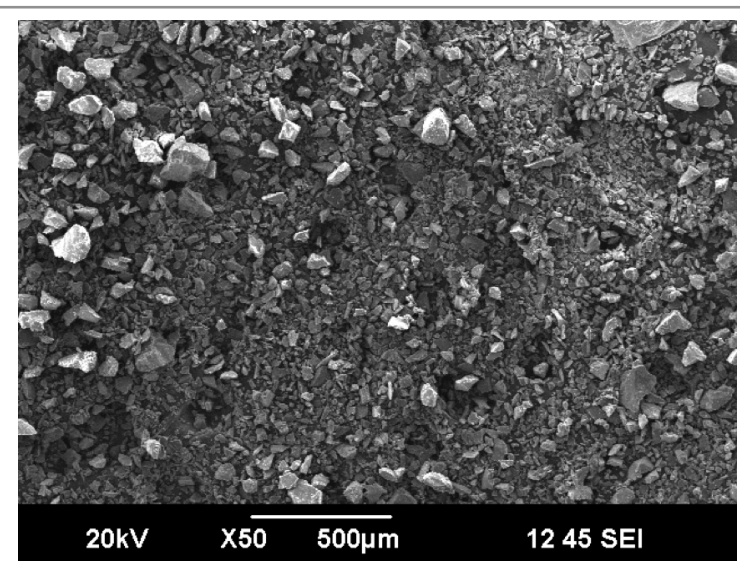

(a)

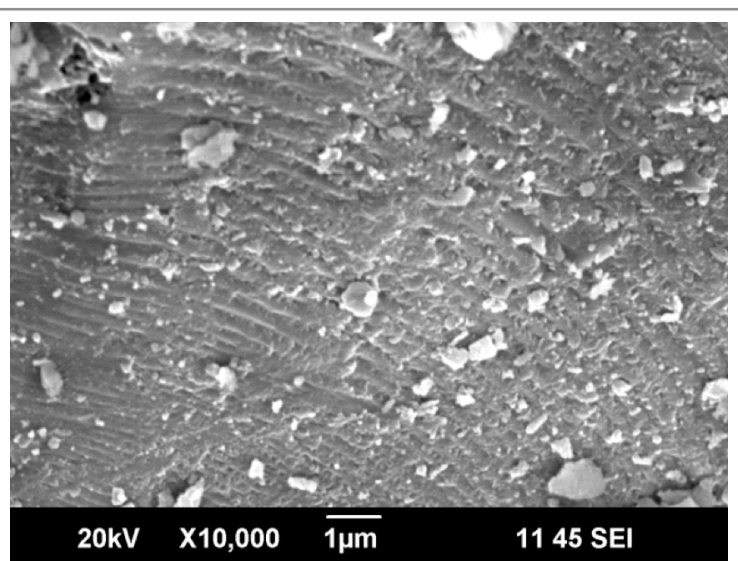

(b)

Figura 4. MEB, Humo de sílice. (a) 50x, (b) 10000x

Figure 4. MEB, Silica fume (a) 50x, (b) 1000x

As shown in Figure 5(a), cement is the most finely grained material in the mixture, with an average diameter of $7 \mu \mathrm{m}$. In Figure 5(b), we can see that the surface of the cement grains is very well defined. They show a softened texture, and they are not totally spherical, whereas silica fume is spherical. 


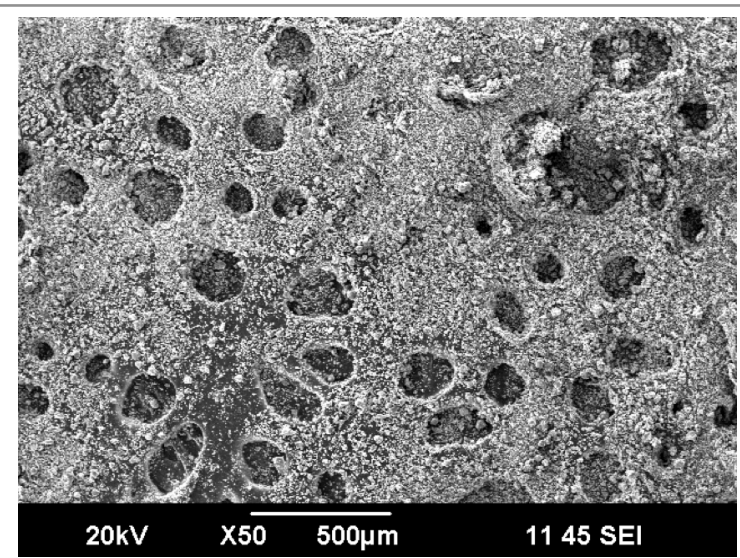

(a)

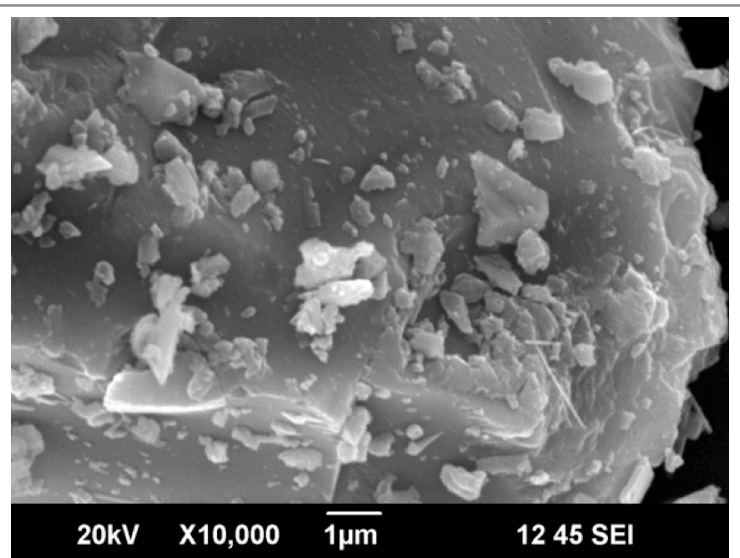

(b)

Figura 5. MEB, Cemento Tipo III. (a) 50x, (b) 10000x

Figure 5. MEB, Cement Type III. (a) 50x, (b) 10000x

\subsection{Study of the material's mechanical behavior 3.2.1 Test mixtures}

We proposed an ideal mixture, as supported by the Fuller distribution and in line with the aspects already mentioned in this paper. By varying the proportions of the materials included in the mixture, we created 4 mixtures with different proportions, so as to evaluate ease of handling and the compression strength of the different mixtures.

The UHPC mixture was designed to optimize the density of the packaging of the dry ingredients. The goal for this mixture is achieved by trying to independently optimize two major phases until the optimal final combination is achieved; the first phase is the paste phase, composed of cement, silica fume, water and the super plasticizing additive; the second is the inert particles phase, which in this case is composed of quartz dust and sand-60.

Table 4 shows the dosages of the mixtures, indicating the proportion of the different components in relation to the amount of cement.

Tabla 4. Dosificación de las mezclas en función de la cantidad de cemento

Table 4. Dosages of the mixtures in relation to the amount of cement

\begin{tabular}{|c|c|c|c|c|}
\hline Material & Mezcla 1/ Mixture 1 & Mezcla 2/ Mixture 2 & Mezcla 3/ Mixture 3 & Mezcla 4/ Mixture 4 \\
\hline Cemento/ Cement & 1.00 & 1.00 & 1.00 & 1.00 \\
\hline Humo de sílice/ Silica fume & 0.25 & 0.25 & 0.25 & 0.20 \\
\hline Arena -60/ Sand-60 & 1.00 & 1.00 & 1.50 & 1.00 \\
\hline Polvo de cuarzo/ Quartz dust & 0.50 & 0.25 & 0.25 & 0.20 \\
\hline Agua/ Water & 0.31 & 0.31 & 0.31 & 0.30 \\
\hline Aditivo/ Additive & 0.09 & 0.075 & 0.075 & 0.07 \\
\hline
\end{tabular}

Using a Fuller granulometric composition, we observed the optimal proportion of sand-60 and quartz powder, approximately $80 \%$ and $20 \%$ respectively. This result is due to the improved accommodation of the materials used in the mixtures in these proportions. 
Figure 6 shows typical curves for the 4 mixtures, for the uniaxial compression strength test at 1, 7 and 28 days. The tested specimens were cubes with sides of $50 \mathrm{~mm}$; these cubes were created following the parameters established in standard ASTM C109. The speed of the application of weight was $0.13 \mathrm{~mm} / \mathrm{min}$.

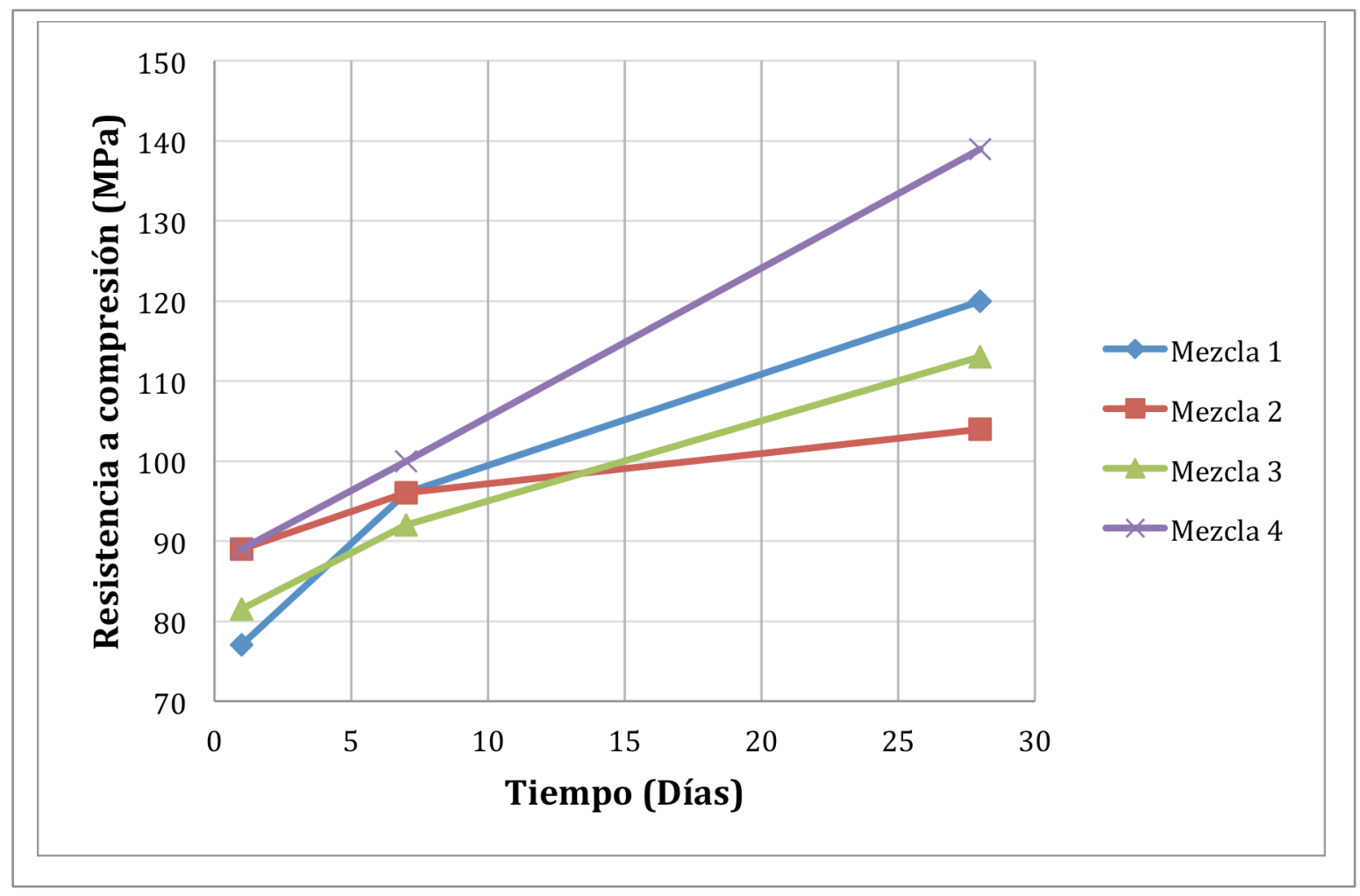

Figura 6. Resultados del ensayo de resistencia a compresión de las diferentes mezclas planteadas Figure 6. Compression strength test results of the different mixtures proposed

As seen in Figure 6, the compression strength obtained on day 1 was above $75 \mathrm{MPa}$ in all of the mixtures; these results are quite high when accounting for the early age when the tests were done.

Once the compression strength tests were done, we used mixture number 4 since, as shown in Figure 6, it is the mixture with the greatest uniaxial compression strength at an age of 28 days, in addition to fulfilling the handling requirements.

\subsubsection{Mixtures with fibers}

Given the mixture's strong performance, specifically in compression strength, we proceeded to test the concrete mixture by adding different quantities of metallic fibers, which were implemented based on percentages of the total volume of the mixture. We chose to do handling, compression strength and modulus of rupture tests, adding $0.5 \%, 1.5 \%$ and $2.0 \%$ of fibers. 
The size of the fibers that were added into the mixture is very important. The ductility level and the traction strength of the concrete mixture are also important; they depend not only on the size of the fibers, but also on the percentage of fibers used per $\mathrm{m}^{3}$. The steel fibers proposed for this mixture are $13 \mathrm{~mm}$ long and $0.018 \mathrm{~mm}$ in diameter.

To estimate the UHPC's modulus of rupture with different contents of metallic fibers, we implemented a series of flexural strength tests, following the recommendations of standard ASTM C580, applying the weight at one third of the clear span .

Figure 7 shows the trend presented by the Maximum Flexural Strength of the joists with different amounts of metallic fibers, tested at 1, 7 and 28 days. We observed that on day 1 , the fibers were not yet sufficiently attached and the flexural strength is practically the same for the different amounts of fibers. The samples tested at 7 and 28 days show that mixtures with metallic fiber amounts lower than $2.0 \%$ have increased performance when there is a higher fiber content, so the performance of the joists with $2.0 \%$ of fibers was superior to the rest.

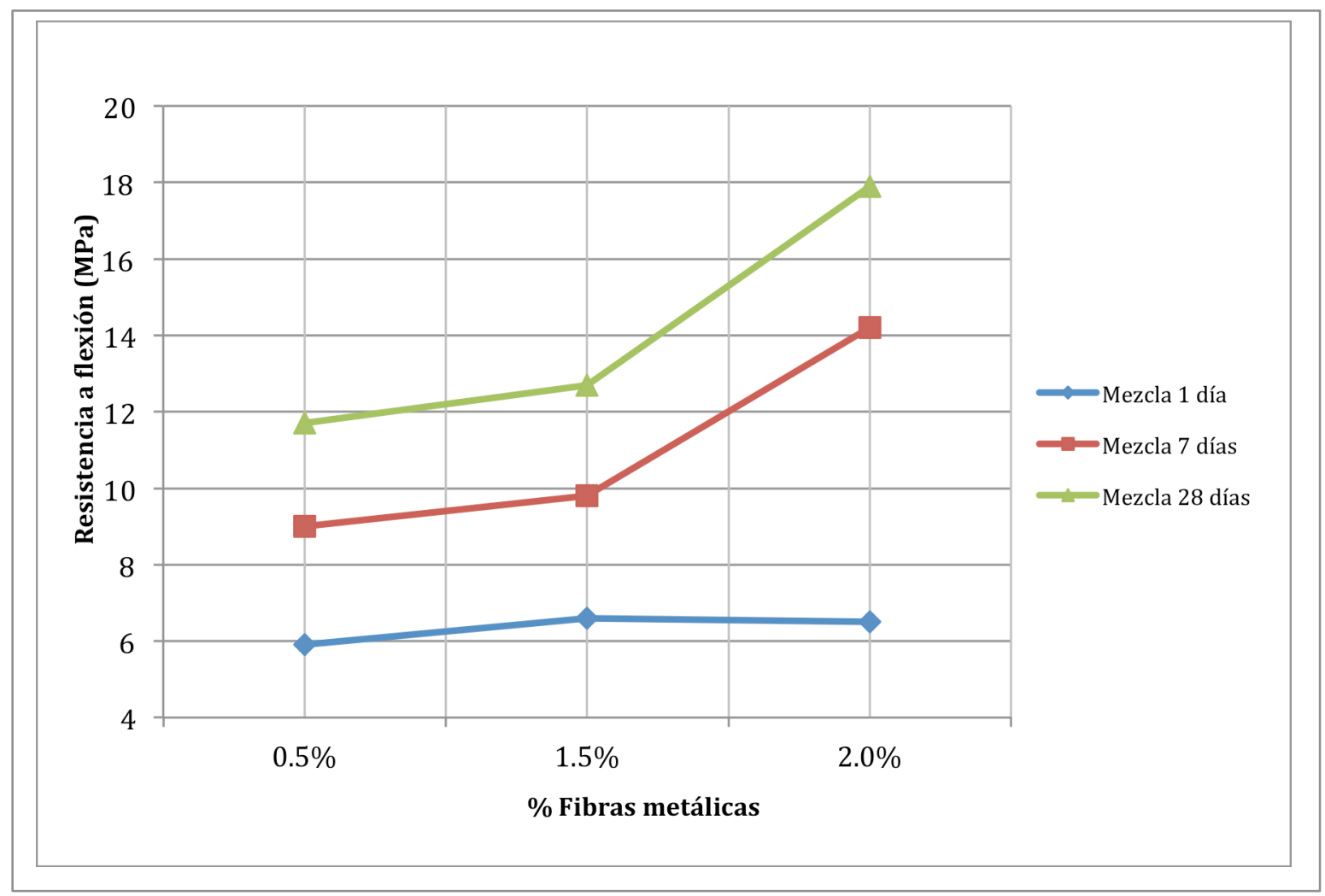

Figura 7. Comparación esfuerzo de flexión, según la edad de las viguetas Figure 7. Comparison of flexural strength, according to the age of the joists 


\subsubsection{Post-crack behavior of fiber-reinforced UHPC}

Given the low water/cement ratio, and the high levels of cement material in the mixture, we assumed that not all of the cement material was able to be hydrated during the mixing process.

To evaluate a possible self-healing process of the concrete, the test specimens were cracked and then subjected to a subsequent curing process to measure average residual flexural strength, keeping in mind the weight registered at deflections 0.50, 0.75, 1.00 y $1.25 \mathrm{~mm}$, as indicated in standard ASTM C1399. The test specimens were cracked at 1, 7 and 28 days, and the re-test was done at 7 and 28 days after the cracking date.

Table 5 shows a summary of the results, comparing the Maximum Flexural Strength obtained in the test specimens that were not cracked, against the test samples that were cracked, on different days. This allowed us to measure their Average Residual Strength (ARS), which was obtained with a re-weighted deflection curve of $0.50,0.75,1.00$ y $1.25 \mathrm{~mm}$, as shown in Formule 1.

$$
A R S=\frac{L}{b \cdot d^{2}}\left(P_{A}+P_{B}+P_{C}+P_{D}\right)
$$

$$
\begin{array}{ll}
\text { Where, } & \\
L: & \text { is the element's clear span }(\mathrm{mm}) \\
b: & \text { is the average width of the element }(\mathrm{mm}) \\
d: & \text { is the average height of the element }(\mathrm{mm}) \\
\left(P_{A}+P_{B}+P_{C}+P_{D}\right): & \text { is the sum of the weights of the deflections } \\
& \text { of } 0.50,0.75,1.00 \text { y } 1.25 \mathrm{~mm}(\mathrm{~N}) .
\end{array}
$$

\begin{tabular}{|c|c|c|c|c|c|c|c|c|}
\hline \multirow[b]{2}{*}{$\begin{array}{l}\text { Porcentaje } \\
\text { fibras/ } \\
\text { Percentage } \\
\text { fibers }\end{array}$} & \multirow[b]{2}{*}{ Ensayo/Test } & \multirow{2}{*}{$\begin{array}{l}\text { Sin fisura/ } \\
\text { Without cracks } \\
\\
\text { Esfuerzo } \\
\text { máximo a } \\
\text { flexión (MPa)/ } \\
\text { Maximum } \\
\text { Flexural } \\
\text { Strength (MPa) }\end{array}$} & \multicolumn{2}{|c|}{$\begin{array}{c}\text { Fisura } 1 \text { día/1 day } \\
\text { Crack }\end{array}$} & \multicolumn{2}{|c|}{$\begin{array}{c}\text { Fisura } 7 \text { días/7 day } \\
\text { Crack }\end{array}$} & \multicolumn{2}{|c|}{$\begin{array}{c}\text { Fisura } 28 \text { días/28 } \\
\text { day Crack }\end{array}$} \\
\hline & & & $\begin{array}{l}\text { Esfuerzo } \\
\text { máximo a } \\
\text { flexión (MPa)/ } \\
\text { Maximum } \\
\text { Flexural } \\
\text { Strength } \\
\text { (MPa) }\end{array}$ & $\begin{array}{l}\text { ARS } \\
(\mathrm{MPa})\end{array}$ & $\begin{array}{l}\text { Esfuerzo } \\
\text { máximo a } \\
\text { flexión } \\
\text { (MPa)/ } \\
\text { Maximum } \\
\text { Flexural } \\
\text { Strength } \\
\text { (MPa) }\end{array}$ & $\begin{array}{l}\text { ARS } \\
(\mathrm{MPa})\end{array}$ & $\begin{array}{l}\text { Esfuerzo } \\
\text { máximo a } \\
\text { flexión } \\
\text { (MPa)/ } \\
\text { Maximum } \\
\text { Flexural } \\
\text { Strength } \\
(\mathrm{MPa})\end{array}$ & $\begin{array}{l}\text { ARS } \\
\text { (MPa) }\end{array}$ \\
\hline \multirow{2}{*}{$0.5 \%$} & 7 días/days & 9.05 & 7.74 & 7.55 & 6.81 & 6.50 & 7.76 & 7.41 \\
\hline & 28 días/days & 11.72 & 8.16 & 7.99 & 8.57 & 8.36 & 9.24 & 7.32 \\
\hline \multirow{2}{*}{$1.5 \%$} & 7 días/days & 9.82 & 9.85 & 7.51 & 11.11 & 10.60 & 13.28 & 12.57 \\
\hline & 28 días/days & 12.73 & 11.84 & 11.43 & 12.34 & 12.05 & 13.95 & 13.43 \\
\hline \multirow{2}{*}{$2.0 \%$} & 7 días/days & 14.15 & 16.93 & 16.88 & 20.05 & 17.95 & 26.77 & 25.16 \\
\hline & 28 días/days & 17.82 & 17.68 & 15.46 & 20.74 & 18.35 & 30.63 & 22.82 \\
\hline
\end{tabular}

Tabla 5. Dosificación de las mezclas en función de la cantidad de cemento

Table 5. Maximum flexural strength and ARS of the test cases of cracked UHPC with fibers 
Table 5 shows that the cracked test specimens reach the modulus of rupture in most cases, even going past that in some cases. We therefore observe that the process of selfhealing is effective, since the material is able to withstand the same load as before the cracking, or even increase the breaking load, with ductile behavior.

When the analysis is focused on the amount of fibers in the test specimen, we observe that the joists with contents equal to $0.5 \%$ gained the least flexural strength, while the ones with $2 \%$ of fibers showed approximately $100 \%$ more flexural strength. Given these results, it is possible to see that the gains in flexural strength and self-healing are highly correlated with the contribution of the fibers and how well they are attached

\section{Conclusions}

Ultra-high performance concrete reinforced with metallic fibers, manufactured with conventional techniques and materials available in Colombia, have features that excel in many different aspects; these characteristics are evident when compared with the performance of a concrete matrix without fibers. Given the high uniaxial compression strength, together with the good flexural performance that can be achieved, fewer sections are required in constructions, and they are therefore lighter.

To obtain the desired performance, we carefully studied the relationship between packaging density and flow capacity in the fresh phase of the concrete, based on the granulometric distribution proposed by Fuller. The dosages proposed in this research were based on the packaging of the inputs, using finely graded material with different average diameters so as to achieve the highest compactness possible. By eliminating larger sized inputs, together with the optimization of the mixture, we were able to create a more homogeneous and denser concrete, which positively influenced its mechanical properties.

For the proposed mixture, we conclude that when creating a dosage with a higher content of metallic fibers, the uniaxial compression as well as flexural strength are notably better. The addition of metallic fibers creates an increase in the concrete to withstand deformation, reducing the most relevant characteristic when it is subject to bending (fragile cracking). The use of silica fume in the mixture's dosage increases the compactness of the mixture, while considerably reducing the exuding of fresh concrete due to its large surface area, allowing us to work with a low water/concrete ratio.

We saw that in all of the proposed analyses, there was a self-healing process of the concrete, which is composed of a curing process after the cracking of the concrete. 
As observed in the analyses indicated above, the adherence of the fibers to the concrete matrix plays a fundamental role in the joist's flexural strength. In fact, for joists that cracked at 28 days of aging, where a large part of the cement material was already hydrated, mechanical abilities improved after the next curing. Likewise, the selfhealing of the concrete's flexural strength is directly related to the fiber content of the concrete. The fiber content must be greater than $1.5 \%$ to ensure that, independent of the age of the cracking, the concrete can maintain, and not lose, its flexural strength.

\section{Referencias/References}

Acker P., Dehloul M. (2004), Ductal ${ }^{\circledR}$ Technology: a large spectrum of properties, a wide range of application. En International Symposium on Ultra High Performance Concrete (pp. 11-23). Kessel (Germany), Septiembre.

Aïtcin P. (2000), Cements of yesterday and today: concrete of tomorrow. Cement and Concrete Research, 30(9), 1349 - 1359, doi: http://dx.doi.org/10.1016/S0008-8846(00)00365-3.

American Concrete Institute (2010), ACl 363 Report on High-Strength Concrete. American Concrete Institute (ACl).

ASTM International (2009), ASTM C29 Standard Test Method for Bulk Density ("Unit Weight") and Voids in Aggregate. American Society for Testing and Materials (ASTM).

ASTM International (2014), ASTM C39 Standard Test Method for Compressive Strength of Cylindrical Concrete Specimens. American Society for Testing and Materials (ASTM).

ASTM International (2013), ASTM C109. Standard Test Method for Compressive Strength of Hydraulic Cement Mortars (Using 2-in. or [50-mm] Cube Specimens) American Society for Testing and Materials (ASTM).

ASTM International (2013), ASTM C117 Standard Test Method for Materials Finer than $75-\mu \mathrm{m}$ (No. 200) Sieve in Mineral Aggregates by Washing. American Society for Testing and Materials (ASTM).

ASTM International (2012), ASTM C128 Standard Test Method for Density, Relative Density (Specific Gravity), and Absorption of Fine Aggregate. American Society for Testing and Materials (ASTM).

ASTM International (2011), ASTM C187 Standard Test Method for Amount of Water Required for Normal Consistency of Hydraulic Cement Paste. American Society for Testing and Materials (ASTM).

ASTM International (2009), ASTM C188 Standard Test Method for Density of Hydraulic Cement. American Society for Testing and Materials (ASTM).

ASTM International (2013), ASTM C191 Standard Test Methods for Time of Setting of Hydraulic Cement by Vicat Needle. American Society for Testing and Materials (ASTM).

ASTM International (2011), ASTM C204 Standard Test Methods for Fineness of Hydraulic Cement by Air-Permeability Apparatus. American Society for Testing and Materials (ASTM).

ASTM International (2013), ASTM C311 Standard Test Methods for Sampling and Testing Fly Ash or Natural Pozzolans for Use in PortlandCement Concrete. American Society for Testing and Materials (ASTM).

ASTM International (2012), ASTM C580 Standard Test Method for Flexural Strength and Modulus of Elasticity of Chemical-Resistant Mortars, Grouts, Monolithic Surfacings, and Polymer Concretes. American Society for Testing and Materials (ASTM).

ASTM International (2011), ASTM C1157. Standard Performance Specification for Hydraulic Cement. American Society for Testing and Materials (ASTM).

ASTM International (2010), ASTM C1399 Standard Test Method for Obtaining Average Residual-Strength of Fiber-Reinforced Concrete. American Society for Testing and Materials (ASTM).

Ashour S. A., Wafa F. F. (1993), Flexural behavior of high-strength fiber reinforced concrete beams. ACl Structural Journal, 90(3), 279-287, doi: http://dx.doi.org/10.14359/4186.

Ashour S. A., Wafa F. F. y Kamal M. I. (2000), Effect of the concrete compressive strength and tensile reinforcement ratio on flexural behavior of fibrous concrete. Engineering Structures, 22(9), 1145-1158, doi: http://dx.doi.org/10.1016/S0141-0296(99)00052-8.

Campione G., Mangiavillano M.L. (2008), Fibrous reinforced concrete beams in flexure: Experimental investigation, analytical modelling and design considerations. Engineering Structures, 30(11), 2970-2980, doi: http://dx.doi.org/10.1016/j.engstruct.2008.04.019.

Chunxiang Q., Patnaikuni I. (1999), Properties of high-strength steel fiber-reinforced concrete beams in bending. Cement and Concrete Composite, 21(1), 73- 81, doi: http://dx.doi.org/ 10.1016/S0958-9465(98)00040-7.

De Larrard F. (1999), Concrete Mixture Proportioning: A Scientific Approach. London: E\&FN Spon.

Espinoza Montenegro A. A. (2010), Estudio de dosificación de hormigón de ultra-alta resistencia, basado en el empaquetamiento de los áridos. (Tesis Máster). Madrid (España): Universidad Politécnica de Madrid.

Jonkers H., Thijssen A., Muyzer G., Copuroglu O., Schlangen E. (2010), Application of bacteria as self-healing agent for the development of sustainable concrete. Ecological Engineering, 36(2), 230-235, doi: http://dx.doi.org/ 10.1016/j.ecoleng.2008.12.036.

Markovic I. (2006), High-Performance Hybrid-Fibre Concrete: Development and Utilisation (PhD Thesis). Delft (The Netherlands ): Technical University of Delft.

Oh B. H. (1992), Flexural analysis of reinforced concrete beams containing steel fibers. Journal of Structural Engineering, 118(10), 2821-2836, doi: http://dx.doi.org/10.1061/(ASCE)0733-9445(1992)118:10(2821).

Oh B. H. (1994) Closure of "Flexural analysis of reinforced concrete beams containing steel fibers". Journal of Structural Engineering, 120(6), 1934, doi: http://dx.doi.org/10.1061/(ASCE)0733-9445(1994)120:6(1934). 
Reda M. M., Shrive N. G., Gillott J. E. (1999), Microstructural investigation of innovative UHPC. Cement and Concrete Research, 29(3): 323329, doi: http://dx.doi.org/ 10.1016/S0008-8846(98)00225-7.

Resplendino J. (2004), First recommendations for ultra-high-performance concretes and examples of application. En International Symposium on Ultra High Performance Concrete (pp.79-90). Kessel (Germany). Septiembre

Richard P., Cheyrezy M. (1995), Composition of reactive powder concretes. Cement and Concrete Research, 25(7), 1501-1511, doi: http://dx.doi.org/10.1016/0008-8846(95)00144-2.

Tue N.V., Küchler M., Schenck G., Jürgen R. (2004), Application of UHPC filled tubes in buildings and bridges. En International Symposium on Ultra High Performance Concrete (pp. 807-817). Kessel (Germany). Septiembre

Van Tittleboom K., De Belie N., De Muynck W., Verstraete W. (2010), Use of bacteria to repair cracks in concrete. Cement and Concrete Research, 40(1), 157-166, doi: http://dx.doi.org/ 10.1016/j.cemconres.2009.08.025.

Wang C., Yang C., Liu F., Wan C., Pu X. (2012), Preparation of Ultra-High Performance Concrete with common technology and materials. Cement and Concrete Composites, 34(4), 538-544, doi: http://dx.doi.org/10.1016/j.cemconcomp.2011.11.005.

Wu M., Johannesson B., Geiker M. (2012), A review: Self-healing in cementitous materials and engineered cementitous composite as a selfhealing material. Construction and Building Materials, 28(1), 571-583, doi: http://dx.doi.org/ 10.1016/j.conbuildmat.2011.08.086.

Yang H., Joh C., Kim B-S. (2010), Structural behavior of ultra high performance concrete beams subjected to bending. Engineering Structures, 32 (11), 3478-3487, doi: http://dx.doi.org/ 10.1016/j.engstruct.2010.07.017. 